\title{
Systematics: Its role in supporting sustainable forest management
}

\author{
by John T. Huber ${ }^{1}$ and David W. Langor ${ }^{2,3}$
}

\begin{abstract}
Understanding the natural world around us requires knowledge of its component parts. From an ecological function perspective, these parts are species. Partitioning the world of living things into distinguishable, universally recognized species, each with a unique scientific name, is difficult, especially when one considers the numerous kinds of microscopic organisms that make up most of the planet's biodiversity. Biosystematics is the study of the origin of biological diversity and the evolutionary relationships among species and higher-level groups (taxa). Taxonomy is the theory and practice of identifying, describing, naming and classifying organisms. Despite the emergence of national and international issues and programs concerning conservation of biodiversity, climate change and invasive alien organisms, all of which demand significant taxonomic input and require an increased investment in systematics, Canada's investment in this discipline has not risen to meet the challenge. Since the mid-1970s the number of taxonomists employed by the federal government has been reduced by about one half. Canada must do more than maintain the inadequate status quo by increasing its investment in systematics in order to meet our nation's obligations, both domestically and internationally.
\end{abstract}

Key words: systematics, taxonomy, definitions, importance for biology, sustainable forestry, biodiversity, invasive pests

La compréhension de l'univers qui nous entoure nécessite une connaissance de tous les éléments qui en font partie. Selon une perspective des fonctions écologiques, ces éléments sont formés d'espèces. La séparation du monde des êtres vivants en fonction d'espèces faciles à distinguer et universellement reconnues, chacune ayant son propre nom scientifique, s'avère difficile, spécialement lorsqu'on considère les nombreuses sortes d'organismes microscopiques qui constituent la majeure partie de la biodiversité de la planète. La biosystématique consiste en l'étude de l'origine de la biodiversité et des relations évolutionnistes entre les espèces et les groupes supérieurs (taxa). La taxonomie regroupe la théorie et la pratique de l'identification, de la description, de la dénomination et de la classification des organismes. Malgré l'émergence d'enjeux et de programmes nationaux et internationaux portant sur la conservation de la biodiversité, sur les changements climatiques et sur les organismes exotiques envahisseurs, tous ces éléments exigent un apport significatif en matière de taxonomie et demandent des investissements accrus en systématique. Les investissements au Canada dans cette discipline ne se sont pas accrus pour répondre aux besoins. Depuis le milieu des années 1970, le nombre de taxonomistes employés par le gouvernement fédéral a été réduit de près de la moitié. Le Canada doit faire plus que le maintien inadéquat du statu quo en accroissant ses investissements en systématique de façon à répondre aux obligations de notre pays tant sur la scène nationale que sur la scène internationale.

Mots-clés : systématique, taxonomie, définitions, importance pour la biologie et l'aménagement forestier durable, la biodiversité, les ravageurs envahissants

\section{Systematics: A Foundation for Biological Sciences}

The biosphere, of which humanity is a part, is created, populated and maintained by a wide variety of biological entities. Human welfare is inextricably linked to this biological world. Despite the fact that human survival and well-being depends on it, we have, at best, only a superficial understanding of its component parts, and how these parts, from genes to ecosystems, are organized and functionally integrated. Human impacts on the biological realm are increasingly pervasive and invasive through resource extraction, environmental pollution, and disruption of naturally evolving processes by movement and modification of genes and species. These rapidly growing influences further challenge our ability to understand the natural world around us. However, humanity is also becoming increasingly appreciative of its dependence on the biosphere, and strives to reduce the undesirable effects of its actions.

\footnotetext{
${ }^{1}$ Natural Resources Canada, Canadian Forest Service, c/o K.W. Neatby Building, 960 Carling Ave., Ottawa, Ontario K1A 0C6. E-mail: huberjh@ agr.gc.ca (Corresponding author)

${ }^{2}$ Natural Resources Canada, Canadian Forest Service, 5320 - 122 Street, Edmonton, Alberta T6H 3S5. E-mail: David.Langor@nrcan-rncan.gc.ca
}

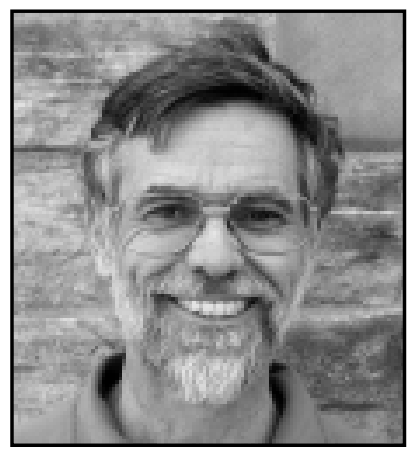

John T. Huber

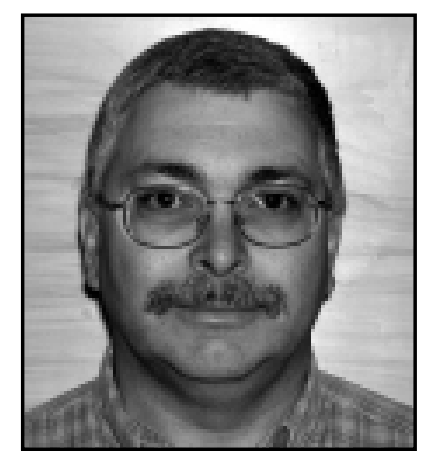

David W. Langor
Fundamental to understanding the workings of a complex system, whether biological or otherwise, is the capacity to identify and understand the role of its component parts. In biological systems these parts, at the most basic level, are genes. However, from an ecological function perspective, the most basic biological entities are species, which are physical and functional manifestations of groups of integrated genes at a specific point in evolutionary time. Humans from all cultures have dis- 
played a natural propensity to classify and identify the biological entities in the world around them, and this propensity was likely strong throughout our evolutionary history because it was linked to survival and prosperity. It is easy to appreciate the need to classify biological entities according to their edibility, danger, medicinal qualities, beauty or other aspects that affect us directly; however, it is not as easy for society to appreciate the need to classify entities that appear to be of no or indirect importance to us, e.g., decomposers, insect parasites and predators, symbiotic bacteria and fungi, and microscopic primary producers such as algae. In practice, the need to partition the world of living things into distinguishable, universally agreed upon entities (taxa), each with a unique name, and organize this diversity into meaningful classifications is very difficult, especially when one takes into account the numerous kinds of small to microscopic organisms that make up most of the planet's biological diversity. In modern times the definition of species has been a topic of considerable debate (e.g., Wheeler and Meier 2000) and delimitation of species involves an element of subjectivity. Nonetheless, dividing the biological diversity surrounding us into recognizable units (species) underpins biological science. Systematics is the branch of science that focuses on recognition and classification of species and the study of their relationships, origin and adaptation (see Box 1). As such, systematics plays a fundamental and unifying role in biology. Furthermore, this branch of science provides us with a common, universal language, i.e., scientific names of species using Latin binomials and their placement into well-founded hierarchical classifications that allow efficient organization and meaningful communication of information about species. Well-founded classifications result in accurate predictions about the biology and potential importance of species whose biology is unknown, simply by reference to closely related species, as determined from the classification.

Paradoxically, as societal awareness and sensitivity concerning biological diversity and the environment has grown over the past 40 years, beginning probably with Rachel Carson's "Silent Spring" (Carson 1962), support for systematics has shown the opposite trend in Canada (Hunter 1991, Ball and Danks 1993). It is beyond the scope of this paper to examine critically the factors contributing to this disturbing trend in systematics support, but undoubtedly a poor appreciation of the fundamental roles and value of systematics is a major factor. While the importance of systematics in forestry (Eidt 1995) and biology in general (Danks 1988) has long been appreciated, the lack of strong advocacy for this branch of science at the highest decision-making levels indicates that systematists have not done a good job at "selling" their science to influential circles where major resource allocation decisions are made. The result has been a continual erosion of resources for support of systematics expertise (i.e., research positions at Canadian institutions), training of students, and infrastructure (e.g., biological collections), in favour of other scientific endeavours. This begs the questions of why systematics has so few voices of influential advocacy and how this problem can be remedied.

The results of science have not generally been well linked to science policy because scientists have often been unable (or unwilling) to demonstrate how their activities relate to policy development, and policy makers have not always been able to communicate effectively their needs to scientists. This problem had already been addressed 35 years ago (The Senate 1970) but apparently with little practical effect. Failure to integrate science and policy can be costly to Canadians, as illustrated by the east coast cod fishery disaster (Jones 2001). Admittedly, science policy issues often develop over a much shorter time frame than that required for scientists to generate and synthesize the information needed to address those issues, sometimes resulting in premature decisions before the facts are available. Also, scientific results may only be a part of the information considered in policy formulation, thus making it appear that science is being given short shrift. However, over the last decade an increasing trend to re-integrate national science and policy has emerged, to the point where government science agendas are being re-structured and re-focused as science-based policy agendas (e.g., Hardy 2002, 2003; Natural Resources Canada 2003) With this fundamental change in the role of science in Canada, as desired by political leaders and implemented by central agencies and departmental management, a clear message is given to the science workforce - science will be judged and supported in large measure on its capacity to support large national and international policy issues as stated, for example, in the National Forest Strategy Coalition (2004) "The long term health of Canada's forests will be maintained and enhanced, for the benefit of all living things, and for the social, cultural, environmental and economic well-being of all Canadians."

The pros and cons of this new paradigm will be observed and debated over time. However, for now, higher-level advocacy and support for particular fields of science will require that decision-makers clearly understand and see, by means of convincing examples, how key science policy development and implementation will benefit from continued investment in these fields. If systematics is to benefit from the increasing and realigning resources invested in science and technology in Canada, systematists must: a) be more active and creative in forging and highlighting links to key science and policy issues; b) ensure that there is continued and widespread appreciation of the contributions of systematics to science policy development and implementation; and c) persuade decision makers that the fruits of systematics research contribute to the prosperity of our nation. This paper focuses on the field of forestry and serves to emphasize how the science of systematics provides fundamental knowledge and tools essential to address adequately key forest science-policy issues in Canada concerning alien invasive species and conservation of biological diversity.

\section{Systematics, Biodiversity and Sustainable Forest Management}

Sustainability is the overriding issue and challenge facing the Canadian forest sector. Sustainable forest management (SFM) demands commitment to a corporate, altruistic philosophy and an investment in actions necessary to safeguard and strengthen, in perpetuity, the ecological, social and economic underpinnings of our nation. The measurement of economic parameters is relatively straightforward, and the metrics, as expressed in dollars, are easily understood. Similarly, it is relatively easy to measure social values because we humans are the target of measurement and we can readily communicate our opinions and perceptions. However, the measurement of appropriate and meaningful ecological parameters remains a major challenge to SFM. The biological diversity (= biodiversity) of forests provides the ecological capital for preserv- 


\section{Box 1 - Defining Systematics}

Systematics is the scientific study of the diversity of organisms (Mayr 1969), including their origin, evolution, diversity and distribution. The central challenge of systematics, and one of the key challenges of science as a whole, is to understand the magnitude and cause of biological diversity (Wilson 1985). The magnitude is put into perspective by comparison with geology, which so far recognizes fewer than about 4500 mineral entities, with no variation among individual specimens of a particular entity. In contrast, there may be millions (we do not know how many - at least 1.2 million are already described) of biological species whose individuals do vary, thus further compounding the problem of distinguishing and identifying species. Systematics includes two major components, biosystematics and taxonomy.

Biosystematics (often considered to be synonymous with systematics) is the study of the origin of biological diversity (speciation) and the evolutionary relationships among species and higher-level taxa (phylogeny). Such research provides us with insight into the origins of biological diversity and helps us to identify and understand patterns in biological diversity. The general body of theory underlying phylogenetic analyses allows for comparisons and syntheses, and generates ideas and hypotheses applicable to other fields of biology (Danks 1988).

Taxonomy is the theory and practice of identifying (discovering), describing, naming, and classifying organisms. Correct identification of biological taxa is a necessary prerequisite to all other enquiries about the biological world. Taxonomists attempt to divide the world of living things (biodiversity) into distinguishable entities (taxa - such as species, genera, families), develop tools (e.g., identification keys) to allow others to recognize and identify these taxa, and organize the described taxa within a hierarchical classification system that reflects evolutionary relationships. The outcomes of taxonomy are, therefore, very practical in terms of providing tools to facilitate identification, an infrastructure for organizing biological information, and a universal language for communicating information about the identity and classification of biological entities. Most people use, usually unknowingly and without due appreciation, the results of taxonomic research on a daily basis in their observations and communications about their environment.

ing ecosystem integrity and allowing adaptation to anthropogenic disturbances. Therefore, biodiversity has been generally recognized as a good indicator of ecosystem functional integration, and, thus, an essential ecological indicator of SFM.

The formal international recognition of humanity's dependence on biodiversity and the crisis of rapid global loss of biodiversity, culminating in the 1992 Convention on Biological Diversity (CBD), have served to focus the attention and actions of society on biodiversity issues. As one of the first signatories to the CBD, and as host of the CBD's Secretariat office, Canada aspires to assume an international leadership role. Canada has articulated its plan to implement the CBD in the form of the Canadian Biodiversity Strategy and has established a Biodiversity Convention Office under the auspices of Environment Canada. Thus, global and Canadian governance structures have been established to help coordinate required actions and facilitate communication among stakeholders. But the systematics expertise required to deal with the biodiversity crisis is inadequate (Catling 2001a) and descriptive and taxonomic information at all levels of biodiversity, distribution and status is incomplete (Stephenson 1994) in Canada and globally. Unless we know and understand the species that occupy particular ecosystems, we have no hope of successfully managing and protecting them (Catling 2001b) or implementing in a meaningful way the CBD.

The interest generated by Canada's drive towards SFM and its commitment to implement the CBD has brought biodiversity issues to the fore. Although there have been some excellent results, at least in terms of generating discussion and bringing additional resources to bear on biodiversity issues, biodiversity science has not kept pace with the expectations demanded of it, especially at the species level. Yet dealing with biodiversity at the species level is essential to developing, refining and measuring meaningful indicators of SFM as acknowledged by the Canadian Council of Forest Ministers (2003) in the following words: "The greatest and most readily recognizable form of biological depletion lies with species extinction. Slowing down the rate of species extinction due to anthropogenic factors is a key objective for the conservation of biodiversity. Changes in species population levels and distribution may provide an early warning of changes in ecosystem stability and resilience..."

Our collective ability to deal with Canada's biodiversity at the species level directly determines our capacity to measure anthropogenic impacts on species diversity, assess these impacts in the context of the range of natural variation in species distribution and abundance, and adapt practices to foster better conservation. Clearly, our excellent knowledge of groups such as vertebrates and vascular plants and our ability to identify them relatively easily has resulted in considerable progress in measuring anthropogenic impacts on them and developing recommendations for their sustainable management. No wonder that these taxa have received the large majority of "biodiversity" resources in Canada. Yet the vast portion of terrestrial species diversity resides in groups that are much more poorly known, e.g., invertebrates, fungi, lichens, and microorganisms. These taxa perform numerous functions essential to maintaining healthy forest ecosystems and they are essential for human survival and well-being. But many are heavily impacted by forest management. For example, among the 1487 redlisted species of Sweden, that have their main occurrence in forest habitats, there are 636 cryptograms (lichens, bryophytes, macro-fungi, stoneworts), 739 invertebrates (mainly insects), 59 vascular plants and 53 vertebrates (Berg et al. 1995). 
However, in Canada very few invertebrates (only eight butterfly species or subspecies) and non-vascular plants are listed as being of special concern, threatened or endangered (COSEWIC 2002), largely because of our ignorance of the vast majority of species in terms of our inability to identify them or adequately assess their distribution, abundance and habitat affinities. Humanity jeopardizes its own well-being if these extremely diverse and poorly-known groups remain ignored or taken for granted for the sake of expediency. Furthermore, if Canada's commitment to SFM is to be taken seriously by the international community, and if market access is to be maintained or improved, demonstration of national commitment to conservation of forest biodiversity in its entirety must be demonstrated.

The largest impediment to inclusion of invertebrates and cryptograms in studies of the impact of anthropogenic disturbances is taxonomy. For example, among arthropods, the taxa that have received most attention in forest biodiversity studies are those that are taxonomically well-known and for which taxonomic resources (e.g., taxonomic expertise, good identification keys, excellent collections) are readily available. These better-studied arthropods include the ground beetles (Coleoptera: Carabidae), rove beetles (Coleoptera: Staphylinidae), butterflies and larger moths (Lepidoptera), spiders (Araneae) and bark- and wood-boring beetles (Coleoptera: Scolytidae, Cerambycidae, Buprestidae), but even some components of these groups offer serious taxonomic challenges. They are not necessarily the best groups to use as indicators of biotic impact and recovery following disturbance, but rather they are the ones most easily accessible taxonomically to non-specialists. Our forests have perhaps half of the estimated 70000 species of insects and mites that occur in Canada. A very small proportion of them are pests, either native or introduced. The great majority are innocuous but in some way are important in the functioning of natural forest ecosystems. Many are excluded from consideration in biodiversity studies because the specimens collected are small, or too difficult and too numerous to identify in a reasonable amount of time, even assuming (optimistically) that they are reasonably well known taxonomically. This does not diminish their importance to the health of forest ecosystems (e.g., LaSalle and Gauld 1991, Clayton and Humble 1999, Grove 2002) but their exclusion, usually for taxonomic reasons, certainly reduces our understanding of forest ecosystems. Without broader investment in the taxonomy of these poorly known groups to create tools that allow incorporation of a broader range of "response variables" (i.e., species) in Canadian biodiversity experiments and monitoring, studies of forest biodiversity will remain seriously handicapped by incomplete knowledge and we may overlook important processes, community relationships, or indicators of ecosystem productivity.

\section{Systematics and Invasive Alien Species}

Canada's forests already have at least 180 species of alien insects feeding on woody plants, about 30 species of invasive alien vascular plants displacing native forest flora, and 5 alien fungi causing widespread diseases and mortality to trees (Hendrickson 2002). Alien insects such as gypsy moth, Lymantria dispar (L.), European spruce sawfly, Gilpinia hercyniae (Hartig), and larch sawfly, Pristiphora erichsonii (Hartig), and fungal diseases such as Dutch elm disease, Ophiostoma ulmi (Buisman) Nannf., and white pine blister rust, Cronartium ribi- cola J.C. Fischer ex. Rabenh., are now widespread, naturalized species that have caused enormous economic losses (Krcmar-Nozic et al. 2000). Mattson et al. (1994) listed 33 scolytid beetles that successfully became established in the United States and Canada; as of December, 2002, 50 species were reported (Haack 2001). Among the bark- and wood-feeding beetles alone, important introductions to Canada in the last decade or so are the Asian long-horned beetle, Anoplophora glabripennis (Motschulsky), brown spruce longhorn beetle, Tetropium fuscum (Fabricius), emerald ash borer, Agrilus planipennis Fairmaire, and pine shoot beetle, Tomicus piniperda (Linnaeus). Increases in international trade, international travel, shipping speeds, container use, and point-to-point shipment provide increased opportunities for exotic organisms to be brought to Canada directly, or indirectly via the United States. Despite substantial efforts at excluding them, alien species introductions into North America continue at an increasing rate (Krcmar-Nozic et al. 2000).

In the United States, timber losses due to exotic pests are estimated at US\$ 4 billion per year (Pimental et al. 2000). The impacts of exotic pests on the Canadian forest sector are largely unmeasured, though their threat to Canadian forests, based on past examples, is documented (Allen and Humble 2002). Assessment of their impact must include measurement of economic, environmental and social parameters (see Box 2). The information currently available suggests that the impact is very significant and is likely to become greater (Krcmar-Nozic et al. 2000). Already, over one-quarter of the flora (Parker and Gill 2002) and about 6\% of beetles (Bousquet 1991) are of foreign origin. Most are confined to man-altered "Europeanized" areas but the relatively few that survive well in natural areas often become serious pests in our forests. Clearly it is in the national interest to stem the flow of undesirable exotic organisms into Canada. Consequently, concerns over invasive alien species have now risen to the top of the forest science policy agenda in Canada.

Over recent years, as Canada's forest science and policy forces have mobilized to focus on invasive alien organisms, it has become evident that systematics plays a major role in addressing this issue. Expert and broadly-knowledgeable taxonomists are the best source of rapid and correct species identifications. The Canadian Food Inspection Agency (CFIA), Canada's first line of defence for intercepting alien organisms, relies greatly upon taxonomists to help them with identification of intercepted organisms. Correct identification of species is the key to accessing other available information, e.g., life cycle, distribution, hosts or impact, thereby building a profile of their likely importance and risk to Canadian resources. However, as less than $2 \%$ of all imported commodities are inspected in the United States (National Research Council 2002) and Canada (B. Gill, CFIA, personal communication) the introduction and establishment of additional alien organisms is highly probable. The spread of established alien pests from the USA into Canada is a likely means of entry, as evidenced recently by the emerald ash borer. The taxonomist's role is even more critical and urgent when it comes to correct identification of exotic organisms found established in trees on Canadian soil. The earlier an established invasive alien species is identified, the greater the chances and the lower the cost of eradication. Delays in identification, incorrect identification, or incomplete identification (e.g., only to genus level) because of lack of Canadian expertise hinders identifi- 


\section{Box 2 - Assessing the cost of invasive alien species in Canadian forests}

\section{Economic costs:}

- timber loss due to reduced tree growth and often tree mortality, and loss of wood quantity and quality;

- wood treatment (e.g., kiln drying) before export;

- revenue loss due to trade restrictions;

- loss of recreational and amenity values;

- regulation, control, mitigation;

- research and development;

- ornamental and shade tree removal and replacement, largely in urban areas.

\section{Environmental costs:}

- changes in genetic diversity of tree species;

- competitive exclusion of native flora and fauna;

- loss or alteration of habitat.

\section{Social costs:}

- loss of aesthetic or spiritual value;

- poor public image, at home and abroad;

- loss of forestry-related jobs and reduction in community stability.

cation of new problems and implementation of appropriate control or eradication measures, with unwanted side effects and wasted time and money.

A pertinent and recent example is that of T. fuscum in Nova Scotia. Although this European woodborer was present in Nova Scotia since at least 1990 (Smith and Humble 2000), the first specimens collected were initially misidentified as a native species. It was not until 1999 that specialist taxonomists correctly identified the species. By this time the species was well established and killing many spruce trees in Point Pleasant Park, Halifax. In May, 2000, the CFIA declared the beetle to be a pest of quarantine significance, and an extensive control and eradication program has been in place since then (Smith and Humble 2000). The cost has been \$4-6 million per year since 2000 (G. Stubbings, CFIA, personal communication), and this may increase because eradication has not yet been achieved and the beetle has spread outside the Park. If experts and tools had been available in 1990 to allow correct identification of this species, it is likely that eradication would have been achieved much sooner and with less cost. Quite simply, investment in systematics can save Canadians money.

Unfortunately, alien species are often not detected until long after their introduction and establishment. This was the case with the Asian longhorned beetle from China, first introduced to New York City and Chicago (Lingafelter and Hoebeke 2002) and highly destructive to hardwood trees, especially maples. This high-profile species was discovered in the Toronto area in September, 2003, and clearly has been present there several years, as evidenced by the relatively large area of infestation (Canadian Food Inspection Agency 2003). Similarly, the emerald ash borer, discovered in Michigan in 2002, had been present there for at least five years before being detected and sent to taxonomists for identification. The infestations in Windsor, however, are much more recent (Scarr et al. 2002). In such cases a taxonomist may provide a quick and accurate identification but it may already be much too late to eradicate the pest. Conversely, an example of rapid detection and expert identification is exemplified by the June, 2003, discovery of the causal agent of Sudden Oak Death, Phytophthora ramorum Werres, De Cock and in't Veld, in one nursery in the lower mainland of British Columbia. Not only was the species of pathogen identified, but also its strain. The subsequent, fast implementation of drastic control measures (by burning all infested stock and surrounding vegetation) resulted in the strain's eradication from Canada. Not only that, but the taxonomist who identified the pathogen proved that it was a European strain not previously reported for North America. He also proved that it arrived in Canada from one nursery in Oregon. The Oregon infestation was also successfully eradicated. Thus, not only was a new strain of a serious pathogen eradicated from North America, but a potential trade embargo on nursery stock from Canada to the US was averted, Furthermore, the eradication of the European strain prevented the possibility of it crossing with another strain already present in the US, which would have resulted in production of sexual stages of the pathogen and potentially far more serious problems.

The role of systematics in addressing invasive alien species issues is, however, broader than provision of identification services. Mere provision of diagnostic services would be analogous to the first part of the proverb: "give a man a fish and feed him for a day, teach a man to fish and feed him for life." More importantly, the science of systematics addresses the second part of the proverb by providing the foundation of knowledge and suite of tools and other resources (e.g., literature and biological collections) that allow taxonomists to provide diagnostic services. The essential, basic and enduring research that taxonomists perform includes: defining and describing species (and higher level taxa) by determining the unique and diagnostic characteristics for each; refining classification systems to allow hierarchical organization of taxonomic information; training and educating non-specialists to apply diagnostic tools; and teaching the science to the next generation of taxonomists. The outputs of taxonomic research range from descriptions of single species to comprehensive taxonomic treatments (revisions) of entire families of organisms for a region, country, continent or even the world. Production of tools and resources such as illustrated identification keys, checklists, catalogues, well-organized and correctly identified specimen collections, and collections of relevant literature all serve to help others, including other taxonomists, make their own identifications. Insights into species distributions and habitat diversity, both necessary prerequisites for meaningful conservation of biodiversity, can only occur once the basic work in systematics has established the means to distinguish and identify species (e.g., Danks 1988). The taxonomic knowledge, tools and resources available today have accumulated over several generations, with constant updates and refinement of the information to reflect more accurately and comprehensively the biological world around us. By spending most of their time describing and classifying the diversity of biological species and building tools to allow wider access to taxonomic knowledge, taxonomists help build a detailed knowledge of Canada's native fauna and flora, which is a necessary prerequisite to identifying non-native alien species. 


\section{Systematics: An Investment in National Prosperity}

In today's world, where economics pervades and dictates our lives more than ever before, the term "natural capital" is very appropriate to help communicate the value of the biological entities that share our world, and how they collectively affect human well-being. In financial terms, capital is the finite amount of money available to an investor to venture in a bid to improve his long-term prosperity. Capital invested wisely will serve the investor well and contribute to his prosperity. Squandered capital rarely returns, and is detrimental to financial (and often physical/emotional/spiritual) well-being. From a biological perspective, the species that populate this world and the functions they provide are essential to human survival and quality of life. These are the resources that humanity exploits and invests to ensure its prosperity and well being. But they are finite and are subject either to wise investment or to being squandered. Once gone, a species can never be brought back. As a country whose prosperity is largely based upon natural resources (particularly biological resources) Canada is particularly blessed but also vulnerable.

Financial systems are organized by having a metric (currency) and measurement (accounting system) that allows investors to track their changes in fortune. Thus, at any point in time, an investor has the capacity to assess status and trends (changes from a baseline), and based on these inputs can make a decision to improve his investment or cut his losses. In the biological world the most useful, functional currency is the species, as this is the variable that most clearly responds to perturbations and is most easily measured. The accounting system is provided by systematics, which provides the means to identify species. This, in turn, allows us to keep track of their presence, distribution and abundance through surveys and ecological studies. Systematics, therefore, provides us with the means to identify correctly the status and trends in our biological capital, thereby allowing modification of our actions to preserve natural capital and better assure a more secure future. Investment in systematics, therefore, is basic to providing the foundation of information and practical tools that allow timely assessment of risk to biological capital. The speed at which threats can be identified and responded to directly translates to economic savings and prosperity.

How is Canada doing with respect to its investment in systematics? Since the mid-1970s the number of taxonomists employed by the federal government has been reduced by about one half (Huber et al. 2001) and the number of university labs offering training in whole organism systematics has declined. In recent years, despite the emergence of national and international issues and programs concerning conservation of biodiversity, climate change and invasive alien organisms, all of which demand significant taxonomic inputs, and require an increased investment in systematics, Canada's investment in this discipline has not risen to meet the challenge. The economic costs of this are now being seen, and will likely increase. We will always need correct identifications for species, whether it be for disease organisms such as the SARS virus, for forest pests such as the Asian longhorned beetle, or for the multitude of other native and exotic species that play a much less visible role in our lives, fields, forests and waters. Moreover, as the current generation of systematists retires, a new generation is needed just to replace them. With the increasing needs for more taxonomic capability, Canada must do more than maintain the inad- equate status quo. Current science-based government policies require that Canada increase its investment in systematics in order to meet our nation's obligations, both domestically and internationally.

\section{Acknowledgements}

We thank Brenda McAfee, Jon Sweeney and Jacques Gagnon for helpful comments on the paper.

\section{References}

Allen, E.A. and L.M. Humble. 2002. Non-indigenous species introductions: a threat to Canada's forests and forest economy. Canadian Journal of Plant Pathology 24: 103-110.

Ball, G.E. and H.V. Danks. 1993. Systematics and Entomology: Introduction. In G.E. Ball and H.V. Danks (eds.). Systematics and Entomology: Diversity, Distribution, Adaptation, and Application. pp. 3-10. Memoirs of the Entomological Society of Canada No. 165.

Berg, A., B. Ehnström, L. Gustafsson, T. Hallingbäck, M. Jonsell and J. Weslien. 1995. Threat levels and threats to red-listed species in Swedish forests. Conservation Biology 9: 1629-1633.

Bousquet, Y. (ed.). 1991. Checklist of beetles of Canada and Alaska. Research Branch, Agriculture Canada, Ottawa, Ont. Publication 1861/E. 430 p.

Canadian Council of Forest Ministers. 2003. Defining sustainable forest management in Canada: Criteria and Indicators 2003. http://www.ccfm.org/2000pdf/CI_Booklet_e.pdf (accessed November 18, 2003).

Canadian Food Inspection Agency. 2003. Asian Long-horned Beetle-Latest Information. http://www.inspection.gc.ca/english/ plaveg/protect/facren/alhbinfoe.shtml (accessed Nov. 10, 2003).

Carson, R. 1962. Silent Spring. Fawcett Publications, Greenwich, CT. 304 p.

Catling, P.M. 2001a. Protecting vascular plant biodiversity in Canada: progress and problems with the taxon approach. In Bioconservation and Systematics. Proceedings of the Canadian Botanical Association Conference Symposium in London, Ontario, June 2000. pp. 62-81.

Catling, P.M. 2001b. A never ending role for biosystematics in the protection of vascular plant biodiversity in Canada. In Bioconservation and Systematics. Proceedings of the Canadian Botanical Association Conference Symposium in London, Ontario, June 2000. pp. 3-27. Clayton, M. and L. Humble. 1999. Microarthropod voucher specimens. Canadian Forest Service, Pacific Forestry Centre, Victoria, BC, Technology Transfer Note No. 19. 6 p.

COSEWIC. 2002. Canadian Species at Risk, May 2002. Committee on the Status of Endangered Wildlife in Canada. 34 p.

Danks, H.V. 1988. Systematics in support of entomology. Annual Review of Entomology 33: 271-296.

Eidt, D.C. 1995. The importance of insect taxonomy and biosystematics to forestry. The Forestry Chronicle 71: 581-583.

Grove, S.J. 2002. Saproxylic insect ecology and the sustainable management of forests. Annual Review of Ecology and Systematics 33: 1-23. Haack, R.A. 2001. Intercepted Scolytidae (Coleoptera) at U.S. ports of entry: 1985-2000. Integrated Pest Management Reviews 6: 253-282. Hardy, Y. 2002. The Canadian Forest Service: New directions for science and technology. The Forestry Chronicle 78: 57-59.

Hardy, Y. 2003. The Canadian Forest Service: agent of change in an evolving forest environment. The Forestry Chronicle 79: 733-739. Hendrickson, O. 2002. Invasive alien species in Canadian forests. In R. Claudi, P. Nantel and E. Muckle-Jeffs (eds.). Alien Invaders in Canada's Waters, Wetlands, and Forests. pp. 59-71. Canadian Forest Service, Natural Resources Canada, Ottawa, ON.

Huber, J.T., S. Darbyshire, J. Bissett and R.G. Foottit. 2001. Taxonomy and Biological Control. In P.G. Mason and J.T. Huber (eds.). Biological Control Programmes in Canada, 1981-2000. pp. 14-22. CABI Publishing, Wallingford, UK. 583 p. 
Hunter, F. 1991. Has the Biosystematics Research Centre been thrown on the compost heap? Bulletin of the Entomological Society of Canada 23: 101-102.

Jones, G.C. 2001. The Canadian North Atlantic cod fishery: a case study of management and conservation policy. In T.W. Clark, M.J. Stevenson, K. Ziegelmayer and M.B. Rutherford (eds.). Species and ecosystem conservation: An interdisciplinary approach. Yale School of Forestry and Environmental Studies, Bulletin No. 105.

Krcmar-Nozic, E., G.C. van Kooten, and B. Wilson. 2000. Threat to biodiversity: the invasion of exotic species. In G.C. van Kooten, E.H. Bulte and A.E.R. Sinclair (eds.). Conserving nature's diversity: Insights from biology, ethics and economics. pp. 68-87. Ashgate Publishing Ltd., Aldershot, England.

LaSalle, J. and I.D. Gauld. 1991. Parasitic Hymenoptera and the biodiversity crisis. Redia 74: 315-334.

Lingafelter, S.W. and E.R. Hoebeke. 2002. Revision of Anoplopho$r a$ (Coleoptera: Cerambycidae). Entomological Society of Washington, Washington, D.C. 236 p. 41 color plates.

Mattson, W.J., P. Niemela, I. Millers and Y. Inguanzo. 1994. Immigrant phytophagous insects on woody plants in the United States and Canada: An annotated list. USDA Forest Service, General Technical Report NC-169. 27 p.

Mayr, E. 1969. Principles of systematic zoology. McGraw-Hill, New York, NY. 428 p.

National Forest Strategy Coalition. 2004. National Forest Strategy (2003-2008), A Sustainable Forest: The Canadian Commitment. Ottawa. $25 \mathrm{p}$.

National Research Council. 2002. Predicting invasions of nonindigenous plants and plant pests. Committee on the Scientific Basis for Predicting the Invasive Potential of Non-indigenous Plants and Plant Pests in the United States, Board on Agriculture and Natural Resources. National Academy Press, Washington, DC. 194 p.
Natural Resources Canada. 2003. The future of science and technology at Natural Resources Canada. Natural Resources Canada, Ottawa, Ont., 17 p.

Parker, D.J. and B.D. Gill. 2002. Invasive species and Biological Control. In P.G. Mason and J.T. Huber (eds.). Biological Control Programmes in Canada, 1981-2000. pp. 1-4. CABI Publishing, Wallingford, UK. 583 p.

Pimental, D., L. Lach, R. Zuniga and D. Morrison. 2000. Environmental and economic costs of non-indigenous species in the United States. BioScience 50: 53-65.

Scarr, T.A., D.G. McCullough and G.M. Howse. 2002. Emerald ash borer. Ontario Ministry of Natural Resources, Forest Management Branch, Forest Health Alert 3.

Smith, G.A. and L.M. Humble. 2000. The brown spruce longhorn beetle. Canadian Forest Service, Pacific Forestry Centre, Victoria, BC, Exotic Forest Pest Advisory 5.

Stephenson, W. 1994. A science assessment of the adequacy of Canada's protected areas network. In Biodiversity Science Assessment Team (eds.). Biodiversity in Canada. p. 199-200. Canadian Wildlife Service, Environment Canada, Ottawa. 245 p.

The Senate. 1970. Science policy for Canada: report on the special senate committee on science policy. Vol.1. A critical review: past and present. [Lamontagne, M. (chairman)]. 327 p.

Wheeler, Q.D. and R. Meier (eds.). 2000. Species concepts and phylogenetic theory: a debate. Columbia University Press, New York, NY. 230 p.

Wilson, E.O. 1985. The biological diversity crisis: a challenge to science. Issues. Science and Technology 1985 (Fall): 20-29. 